\title{
The 'Eco Swiss' Doctrine Con-firmed in Principle in Danish Law
}

Bergqvist, Christian; Christensen, Laurits Peder Schmidt

Published in:

The 'Eco Swiss' Doctrine Con-firmed in Principle in Danish Law

Publication date:

2016

Citation for published version (APA):

Bergqvist, C., \& Christensen, L. P. S. (2016). The 'Eco Swiss' Doctrine Con-firmed in Principle in Danish Law. In The 'Eco Swiss' Doctrine Con-firmed in Principle in Danish Law Social Science Research Network (SSRN). 


\title{
THE "ECO SWISS" DOCTRINE CONFIRMED IN PRINCIPLE IN DANISH LAW
}

\author{
Denmark, Eco Swiss, ordre public, arbitration, horizontal corporation \\ By Christian Bergqvist, Ph.d. Associated Professor, University of Copenhagen, and Laurits \\ Schmidt Christensen, Associate Partner, Attorney-at-Law, Accura Law firm
}

\section{Summary of the case}

In a January 2016 ruling the Danish Supreme Court rejected the argument that a 2011 arbitration award infringed competition law and therefore should be set aside. ${ }^{1}$ The dispute between the parties pertained to the termination of an international distribution agreement between a South Korean and a Danish company. The losing party in the arbitration proceedings had raised a competition law-based argument before firstly the High Court and subsequently before the Supreme Court as one of more grounds for overturning the arbitration award. By its January 2016 ruling the Supreme Court upheld the decision of the High Court, and - indirectly the decision of the arbitration tribunal. The arbitration tribunal interpreted the parties' agreement to the effect that it did not as such impose an exclusivity obligation. In the absence of such clear restrictions, the arbitration tribunal had found that the parties' agreement was not contrary to competition law.. While the facts of the case may indicate that the arbitration tribunal did not apply an overly rigid interpretation of competition law, the parties and the arbitration tribunal had undeniable spent time and energy on considering the issue. In this regard, the tribunal has tabled questions directly to the parties on the application of Article 101 to the distribution agreement. Although this is not articulated directly by the Supreme Court (and the High Court), it would be plausible to accept that both courts took comfort in the analysis of the arbitration tribunal when they were called upon to consider the question. More importantly is however that with this ruling the Danish Supreme Court explicitly has reserved the right of the ordinary courts to review and overturn arbitration tribunal decisions which do not adequately take into consideration competition law issues. Thereby the EU competition law Eco Swiss doctrine ${ }^{2}$ has been recognized in principle as a part of Danish law mandating that arbitration tribunals must take competition law into consideration in circumstances where under national procedural law it would set aside an arbitration award on ordre public grounds. Failing to do so may lead to an arbitration award being overturned by the ordinary courts.

\section{Background of the case and its road to the Supreme Court}

The dispute underlying the Supreme Court's decision of January 2016 can be traced back to a distribution agreement concluded in 2006 between Taewoong Inc, a South Korean undertaking, and the Danish company $A H$ Industries $A / S$. AH Industries $A / S$ was to distribute flanges produced by Taewoong. Flanges are typically welded components used to strengthen or connect parts of a construction e.g. different parts of a wind turbine/tower. Prior to the agreement both parties had provided flanges to the wind turbine industry albeit using different technologies.

\footnotetext{
${ }^{1}$ Hojesterets dom af 28. januar 2016 i sag 142/2014 - Taewoong Inc vs. Ah Industries A/S. A large part of the arbitration award is summarized and in parts cited in the High Court ruling which was the subject of appeal, Vestre Landsrets 9. afdeling dom af 4. Juni 2014 i sag V.L.B-2245-11 - Taewoong Inc vs. Ah Industries A/S.

${ }^{2}$ Case C-126/97 - Eco Swiss China Tim Ltd v. Benetton International NV, ECR 1999, I.p.3079.
} 
While titled as a distribution agreement it would arguably be possible to view the arrangement as a horizontal specialization arrangement or plainly as a distribution agreement between competitors. According to the terms of the agreement AH Industries would, rather than produce flanges itself or by sub-suppliers, henceforth cover its requirements from Taewoong. Taewoong would allegedly in return refrain from supplying flanges directly to customers in Europe, USA and South America. Therefore, the agreement would appear to have included an element of exclusivity - the precise scope and strength of which was disputed by the parties during the proceedings - that limited Taewoong from soliciting customers without the involvement of $A H$ Industries during the term of the agreement as well as for two years post-termination. Furthermore, according to Taewoong the parties held a combined market share exceeding 20 per cent of the worldwide market for flanges for wind turbines. This apparently had some support in a report prepared by a third party expert. The relevant market was allegedly characterised by a high level of concentration, high entry barriers and excessive capacity. Both the combined market share and these market characteristics were disputed by AH Industries. AH Industries also disputed that the parties should be viewed as competitors. From a competition law perspective a reading of the agreement confining Taewoong to Asia could be problematic in light of the concentrated market and the horizontal overlap of the parties' activities.

Following the conclusion of the distribution agreement in 2006 some minor adjustments were agreed between the parties in 2007. More importantly was, however, that the corporation between the parties somehow went sour, eventually leading to the termination of the agreement by Taewoong in 2007, and in this process Taewoong made sales which could be seen as a breach of the alleged exclusivity. As the agreement included provisions referring any disagreements to arbitration under Danish law AH Industries initiated arbitration before the Danish Arbitration Tribunal in 2009. AH Industries argued that Taewoong had breached the terms of the agreement and acted disloyally, e.g. by approaching and selling to certain customers directly. On this basis AH Industries claimed compensation equal to its lost turnover estimated at DKK 150 million (EURO 20.1 million). In response Taewoong submitted that it had neither breached the distribution agreement nor had it in the first place accepted any exclusivity obligations as this would not have served its interests and moreover would have been in contravention of Article 101. In addition, Taewoong argued that even if it should be seen to have accepted some form of exclusivity obligations, enforcing such exclusivity would be an infringement of Article 101, and therefore any such exclusivity provisions would be null and void. Conversely, AH Industries submitted to the arbitration tribunal that Article 101 did not prevent the enforcement of the alleged exclusivity obligations.

\section{Decision of the arbitration tribunal and subsequent litigation at the courts}

The arbitration tribunal held that the concluded arrangement was as a 'normal' distribution agreement giving each of the parties certain rights and obligations including an obligation to act in good faith. The tribunal found that Taewoong had failed to act loyally and that this breach of the agreement entitled $A H$ Industries to a compensation of DKK 20 million (EURO 2.68 million). In support of this the arbitration tribunal found that while the disputed clause did not grant $A H$ Industries exclusivity as such, it nevertheless entitled $A H$ Industries to some degree of priority when it came to end-customers that it had built up in the interest of Taewoong. Therefore, AH Industries had a right to compensation as Taewoong had sold flanges to these customers directly. In reaching this finding the tribunal carefully reviewed the concluded 
agreement, including drafts and various email correspondence. The tribunal had also requested each party to provide their views on the nature of their contractual relationship (vertical or horizontal) under Article 101 and whether this invalidated part of the agreement. Irrespective of the submission of detailed arguments in support of the competition-law based argument before the arbitration tribunal by Taewoong, including the argument that the agreement involved two competitors with a 20 per cent joint market share, the arbitration tribunal did not find any competition law infringement which would result in the setting aside of the disputed provision. It is reasonably to conclude that while the actual interpretation of and conclusion in relation to Article 101 may be discussed, the tribunal was indeed minded to consider in detail the competition law submissions in support of different interpretations of the disputed provision. However, the tribunal did not explain its Article 101 analysis in great detail, but rather cut the analysis short in that it found that on a correct interpretation the agreement did not impose exclusivity obligations or only imposed a 'soft' exclusivity obligation on Taewoong. Moreover, the tribunal does not appear to have separately considered in great detail the possible anticompetitive intent or effect of the 2-year post-termination element of the provision. It is therefore not clear whether the tribunal viewed the parties as competitors or non-competitors, whether the arrangement was viewed as purely vertical, and whether in the view of the arbitration tribunal also competitors can conclude customary distribution agreements.

Discontent with several elements in the arbitration award, including the dismissal of the competition law-based argument, Taewoong challenged the award before the ordinary courts, which in first instance was The Danish High Court. While such appeal was in principle excluded as a consequence of the arbitration clause, the Danish Law on Arbitration nevertheless provides for an exception in cases of conflicts with fundamental principles of law of ordre public nature. This provision is in line with general recognised arbitration law principles as well as the EU law Eco Swiss doctrine that national courts can set aside an arbitration award conflicting with competition law. However, while confirming having the power to overturn an arbitration award conflicting with competition law in principle, neither the High Court nor the Danish Supreme Court found grounds for doing so in relation to the matter at hand. Neither of the two courts provided detailed reasoning for their conclusions. It would appear that the courts to a large extent confined themselves to relying on the analysis carried out by the arbitration tribunal. ${ }^{3}$ Consequently, the arbitration tribunal award was upheld. Moreover, Taewoong was ordered to cover the costs of $A H$ Industries before the High Court and the Danish Supreme Court.

\section{What to extract from the Supreme Court ruling?}

Neither the Supreme Court nor the High Court offered detailed reasoning for their conclusions in relation to the competition law point. However, it is safe to conclude that in principle it is

\footnotetext{
${ }^{3}$ The High Court states: "Based on the content of the decision of the arbitration tribunal in combination with the information [in the arbitration decision] about the detailed consideration of the competition law issue in the course of the arbitration proceedings, there are no grounds for determining that the arbitration tribunal in its decision has omitted to consider the question of whether the results of its interpretation involved an infringement of EU competition law" (our translation). The Supreme Court noted that the arbitration tribunal - based on its interpretation of the contractual obligations which the parties' agreement included - did not find that obligations of this nature infringed EU competition law. The Supreme Court noted that it did not have a basis for determining that the arbitration tribunal by making this assessment had made such substantially grave errors that the award was manifestly incompatible with ordre public principles.
} 
possible under Danish law to have an arbitration award overturned on the ground of failure by an arbitration tribunal to adequately take competition law into consideration. As the Supreme Court in its analysis of the arbitration award mentions the absence of substantially grave errors ("overordentligt graverende fejl") which would have made the award manifestly incompatible ("åbenbart uforenelig") with ordre public principles, it would also be reasonably to submit that the review and possibility of having arbitration awards overturned by the courts on this ground are limited. The test would appear to be a difficult test for the courts to define and apply in relation to alleged competition law infringements. On one hand a court would arguably need to review and analyse the facts and the substance of the matter to determine whether there was in fact a material breach of competition law. On the other hand, the court's powers are limited to situations where the decision of the arbitration tribunal is manifestly incompatible with competition law which would indicate that a review of the arbitration tribunal's reasoning would be sufficient.

The possibility of having arbitration awards overturned may be limited. These would include situations where the arbitration tribunal has completely failed to take into consideration relevant competition law arguments or has refused to consider their relevance. While the conclusion of the arbitration tribunal in the present matter may possibly be based on a 'not-too-rigid' reading of Article 101, the Arbitration Tribunal would appear to have considered the question in detail. As a final observation it could be submitted that an arbitration tribunal may be less willing than an ordinary court in a direct action to accept competition law arguments in favour of an interpretation that sets limits to the parties' contractual freedom and rebalances the contract given that the tribunal has indeed been set up by the parties for the purpose of adjudicating their contractual dispute. 